\title{
Shared or distinct responses between intermediate and satellite stream fish species in an altered Amazonian River?
}

\author{
María Angélica Pérez-Mayorga • Lilian Casatti • \\ Fabrício Barreto Teresa • Gabriel Lourenço Brejão
}

Received: 23 December 2016 / Accepted: 6 August 2017 /Published online: 17 August 2017

(C) Springer Science+Business Media B.V. 2017

\begin{abstract}
Environmental and spatial variables can distinctly influence the occupancy frequency distributions in stream fish. From a metacommunity context, we tested the following hypothesis, intermediate species are governed by dispersal and niche-based processes; in contrast, satellite species are governed by niche-based processes. To test this, we separately analyzed three data sets, the entire metacommunity, the intermediate species and the satellite species, using a forward selection of explanatory variables, and a partial Redundancy Distance Analysis. The fish and 31 variables of 52 stream reaches of a Brazilian river basin in the Western Amazon were collected during the dry period of 2012. The results for all of the data set revealed two different patterns: on one side, satellite species revealed that niche and dispersal-based processes were the most important; on the other side, for intermediate species and for all of the species set, only dispersal-based processes were the most important. For the data set including all of the species and the intermediate species, the variance was explained mainly by landscape scale variables. By
\end{abstract}

Electronic supplementary material The online version of this article (doi:10.1007/s10641-017-0663-5) contains supplementary material, which is available to authorized users.

M. A. Pérez-Mayorga $(\bowtie) \cdot$ L. Casatti · G. L. Brejão Departamento de Zoologia e Botânica, Universidade Estadual Paulista UNESP, São José do Rio Preto, São Paulo, Brazil e-mail: anyelicaperez@yahoo.com

F. B. Teresa

Unidade de Ciências Exatas e Tecnológicas, Universidade Estadual de Goiás UEG, Anápolis, Goiás, Brazil contrast, the variance within the satellite species set was explained by local scale variables. Management efforts for intermediate species should be taking at larger scale, but they are usually less critical for the maintenance of aquatic biodiversity; on the other hand, management efforts for satellite species should be taken at smaller scale and based on specific biological and ecological information for the focal species.

Keywords Amazonian ichthyofauna $\cdot$ Land cover change - Deconstructive framework - Occupancy frequency distributions - Niche and dispersal-based processes $\cdot$ Metacommunity

\section{Introduction}

Metacommunities can be defined as a set of local communities that are linked by the dispersal of multiple potentially interacting species (Gilpin and Hanski 1991; Leibold et al. 2004). Dispersal in the metacommunity context is the unidirectional or bidirectional movement of individuals from donor populations (emigration) to potential colonization sites (immigration) (Leibold et al. 2004), this concept is often mistaken for two other organism relocation forms, movement and migration (Jacobson and Peres-Neto 2010). Movement works on the smallest scale and encompasses normal foraging movements and any behavior within the organisms home range (McMahon and Matter 2006; Jacobson and Peres-Neto 2010); and migration is linked to the population scale (Jacobson and 
Peres-Neto 2010) and is the cyclical distant movement of individuals or populations away from their source (Nathan et al. 2003; Jacobson and Peres-Neto 2010).

According to the significant variance of the pure environmental fraction and/or pure spatial fraction for a data set it is possible identify the importance of nichebased processes and/or dispersal-based processes, this approach would offer potential causal mechanisms for revealing a variety of metacommunity models in nature (Cottenie 2005). The relative importance of different processes may vary for different species groups as species clustered according to their functional traits (Algarte et al. 2014), their specialization degree (Pandit et al. 2009) or their rarity (Heino and Soininen 2010; Siqueira et al. 2012; Petsch et al. 2015). This deconstructive framework consists in "turning to the roots" of what is being examined, or "disaggregation," to make recognizable what is undetected (Marquet et al. 2004) and can be a useful way to test hypotheses that go beyond the simple identification of the relative importance of spatial and niche-based processes in modeling the community structure as a whole (Algarte et al. 2014). For example, Pandit et al. (2009) demonstrated that habitat specialists are governed by niche processes and habitat generalists are governed by regional processes. This approach could be more informative, suggesting different predictions about the dynamics of specialists and generalists under different metacommunity models.

In communities with high species richness, it is more difficult to understand the relative importance of environmental versus spatial factors on community dynamics. Therefore, it is necessary and recommended partitioning the communities to detect ecological patterns (Marquet et al. 2004). Freshwater fish communities represent good models for metacommunity studies due to the following characteristics: (a) they are restricted to the aquatic environment and are influenced by both local and landscape scales (reach, stream, microbasin, and basin) (Schlosser 1991; Fausch et al. 2002; Pusey and Arthington 2003; Lorion and Kennedy 2009; Fernandes et al. 2012); (b) they have a good relocation capacity (Schlosser 1991; Fausch et al. 2002), which is influenced by the spatial scale; (c) they can be classified in groups according to their feeding tactics and micro and mesohabitat use (Brejão et al. 2013). In addition, fish communities from the tropics come from diverse ecosystems, often with great richness and abundance compared to temperate communities (Lowe-McConnell 1975). In view of the foregoing, classifying species according the form of their occupancy frequency distribution (OFDs) (i.e. satellite species, intermediate species, core species) may be a good way to handle rich fish community data from tropical regions.

Hanski (1982) defined three groups according their OFDs: core species, regionally common and locally abundant and relatively well spaced-out; satellite species, regionally and locally rare species; and intermediate species, located between the satellite species and core species. Posteriorly, Tokeshi (1992) proposed a test to evaluate three distribution patterns in communities: bimodal, evidences dominance of satellite and core species; single-modal, evidences dominance of satellite species (positive skew) or core species (negative skew); and uniform, evidences that not support a pattern.

In the present study, we used a deconstructive approach based on OFDs, to explore the processes (nichebased processes and/or dispersal-based processes) shaping the metacommunity structure of stream fish fauna. The previous evidences showed that satellite species respond to niche-based processes (according habitat specialization Pandit et al. 2009; according OFDs Heino 2015) and core species respond to dispersalbased processes (according habitat specialization Pandit et al. 2009), then is expected that intermediate species respond to both processes, niche-based processes and dispersal-based processes. We divided fish species from the Machado River basin into three groups according to their occupancy frequency distribution, which was determined on the basis of species occurrence patterns: intermediate species, satellite species and all species group. We predicted that three responses might be applicable to our data set:

(1) intermediate species will respond to spatial variables (dispersal-based processes) based on the interfluvial distance among streams and distance among subbasins, proxies for dispersal limitation; and also, will respond to environmental variables (niche-based processes). This prediction assumes that intermediate species has broad environmental and spatial tolerances, so both, environmental and spatial variables will account for little variation in their abundance and spatial distribution;

(2) on the other hand, we predicted that the satellite species would be explained mostly by environmental variables (niche-based processes). This prediction assumes that species with very specific habitat requirements have a strong relation with 
environmental variables. For example, some stream fish species are associated exclusively to coarse litter (Carvalho et al. 2013), hard substrates (Casatti and Castro 1998) (gravel, cobble and boulder) or woody elements (branches and tree trunks, fine roots, exposed coarse roots, and coarse litter); and

(3) considering the species abundance distribution theory (May 1975; Pielou 1975; Hughes 1986), where most of the species are represented by a small number of individuals (Hughes 1986) (e.g., the satellite species), and most of the individuals belong to a small number of abundant species (Hughes 1986) (e.g., the core species), we expected that the entire metacommunity group would reveal the same pattern as the intermediate species (niche-based processes) due to the influence of their high species richness.

\section{Methods}

Study area

The Madeira River, in the Brazilian Amazon, is an example of highly diverse system. Contrary to most tropical waters in the world, the fish fauna of this region is sufficiently known because of recent efforts from taxonomists, who documented 920 species (TorrenteVilara et al. 2013). For the entire Madeira basin, the number cited by Torrente-Vilara et al. (2013) is probably underestimated because streams and the upper region of the basin were not sampled. For example, in a tributary basin of the Madeira River (the Machado River), the stream fish fauna comprised 140 species, some of them with a small range of distribution (Casatti et al. 2013).

The Machado River is a tributary on the right side of the Madeira River, in the Western Amazon. The Machado River basin is situated in the state of Rondônia, Brazil (Fig. 1), comprises 13 subbasins (ANA 2017), 75,400 $\mathrm{km}^{2}$, with an altitude gradient that varies between 75 and $600 \mathrm{~m}$ (Krusche et al. 2005). The main soil types in the basin are represented by oxisol and ultisol (47 and 24\% of the total, respectively, Ballester et al. 2012). The climate is tropical monsoon (Alvares et al. 2014), with an average temperature varying between 19 and $33{ }^{\circ} \mathrm{C}$ and annual average precipitation of approximately $2500 \mathrm{~mm}$ (Krusche et al. 2005). The hydrological regime in that basin consists of a dry period between June and December, with the lowest level between August and September, and a rainfall period between January and May, with the highest level in February, according to data available by ANA (2017).

Since the 1970s, the Machado River basin has been modified with the introduction of settlement projects along the inter-state highway (Alves et al. 1998) that connects the southeast state of São Paulo to the western state of Acre. The central portion of the basin demonstrates high levels of human influence, with large livestock areas; the upper and lower portions of the basin are less modified, with higher proportions of forests (Krusche et al. 2005). The vegetation can be classified into three stages (Ferraz et al. 2005): (i) open primary wet tropical forest, with no sign of disturbance and trees of 20 to $40 \mathrm{~m}$ height; (ii) secondary forest, resulting from abandonment of cleared forest lands generally from agriculture (Brown and Lugo 1990), and trees of 5 to $20 \mathrm{~m}$ height (Fernandes et al. 2012); and (iii) pasture grasses, without forests, which include livestock farms (Fernandes et al. 2012).

\section{Sampling design}

We restricted our sampling to 'terra-firme' streams in order to standardize the type of stream that would be sampled. According to Pazin et al. (2006), the term 'terra-firme' refers to tropical rain forests that are not seasonally inundated by the surrounding rivers. Therefore, the sampled streams were not seasonally flooded, as other types of streams in the Amazon are. The streams were chosen through thematic maps produced a priori. We generated a hydrographic network using the ArcSWAT hydrological model based on SRTM DEM satellite images $(90 \times 90 \mathrm{~m}$ resolution $)$, which were originated from NASA and made available by the United States Geological Survey (USGS), considering 1000 ha as the minimum contribution area. Then, we requested the ArcSWAT to define microbasin limits, ranging from 1000 ha to 5000 ha. The term microbasin become popular due to the need to emphasize the work of local extension with a small number of properties that together occupy an area ranging from 1000 to 10,000 ha of land (Resck 1992).

In the field, we chose sites that were $<1.5 \mathrm{~m}$, perennial, and accessible; after doing this in situ selection, we sampled 52 stream reaches. Each reach was $80 \mathrm{~m}$ long and was sampled during the dry period, in June and July of 2012. 


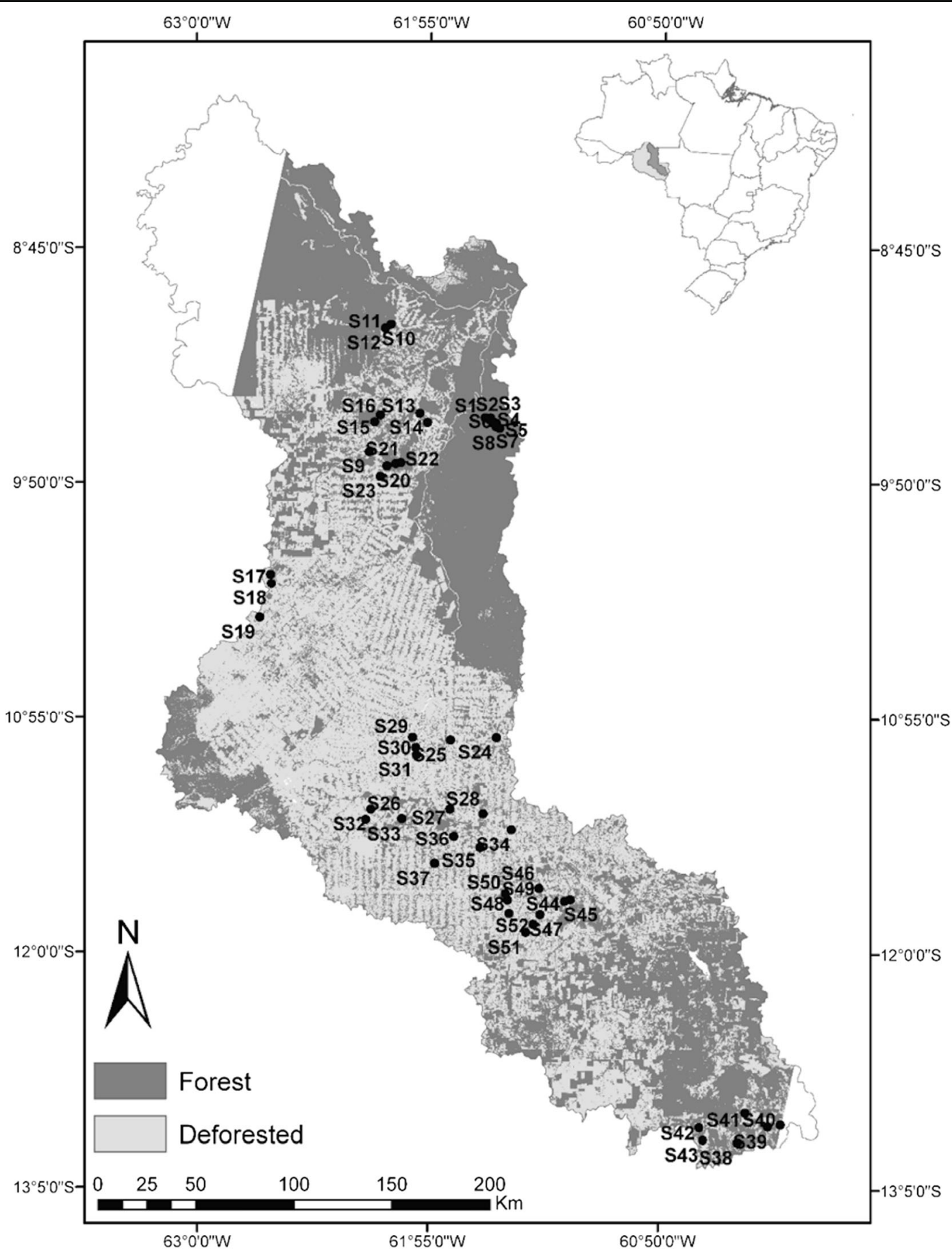

Fig. 1 Location of the Machado River basin in the State of Rondônia (Brazil) (top right), the two main categories of soil coverage (forest and deforested) and location of the 52 stream sampled reaches (filled circles)

Sampling of variables

We sampled 29 environmental variables that were subdivided into local environment variables $(\mathrm{S}=23)$ and landscape variables $(\mathrm{S}=6)$, we used the standard deviation to assess the heterogeneity of local variables and the percentage for the landscape variables (Table 1). The six subsets of environmental variables measured 
Table 1 Environmental (local and landscape) and spatial variables and their sampling description. Values are means $(\mathrm{M}) \pm$ standard deviation (SD)

\begin{tabular}{|c|c|c|c|}
\hline Scales & Variables & $\mathrm{M} \pm \mathrm{SD}$ & Description \\
\hline \multicolumn{4}{|l|}{ Local } \\
\hline \multirow[t]{2}{*}{ Hydrological } & $\begin{array}{l}\text { DEP } \\
\text { WID }\end{array}$ & $\begin{array}{l}15.6 \pm 7.8 \\
3.0 \pm 1.5\end{array}$ & $\begin{array}{l}\text { We took several measurements in each } \\
\text { stream reach, and then calculated the } \\
\text { standard deviation }\end{array}$ \\
\hline & CUR & $0.5 \pm 0.3$ & $\begin{array}{l}\text { We took four measurements every } 20 \mathrm{~m} \text { in } \\
\text { each stream reach, and then calculated the } \\
\text { standard deviation }\end{array}$ \\
\hline \multirow[t]{2}{*}{ Physicochemical } & $\begin{array}{l}\text { WTE } \\
\text { DOX }\end{array}$ & $\begin{array}{l}23.4 \pm 1.8 \\
6.6 \pm 2.1\end{array}$ & \multirow{2}{*}{$\begin{array}{l}\text { Before fish sampling and net installation, } \\
\text { we took one measurement in downstream } \\
\text { section for each stream reach }\end{array}$} \\
\hline & $\mathrm{CON}$ & $24.8 \pm 22.3$ & \\
\hline \multirow[t]{7}{*}{ Substrate } & $\begin{array}{l}\text { SIL } \\
\text { SAN }\end{array}$ & $\begin{array}{l}8.2 \pm 22.1 \\
53.3 \pm 27.9\end{array}$ & \multirow{7}{*}{$\begin{array}{l}\text { We used the Krumbein and Sloss (1963) substrate } \\
\text { classification. We quantified on field the } \\
\text { percentage values of substrate composition } \\
\text { every } 20 \mathrm{~m} \text { for each stream reach, and then } \\
\text { calculated the standard deviation }\end{array}$} \\
\hline & GRAV & $3.7 \pm 7.3$ & \\
\hline & BOU & $5.3 \pm 1.2$ & \\
\hline & BED & $1.2 \pm 8.7$ & \\
\hline & AVE & $1.9 \pm 4.9$ & \\
\hline & CLI & $18.8 \pm 17.4$ & \\
\hline & BAT & $12.5 \pm 12.2$ & \\
\hline \multirow[t]{8}{*}{ Riparian buffer } & $\begin{array}{l}\text { FRO } \\
\text { CRO }\end{array}$ & $\begin{array}{l}2.2 \pm 5.5 \\
4.1 \pm 7.7\end{array}$ & \multirow{8}{*}{$\begin{array}{l}\text { We quantified on field the percentage values of } \\
\text { riparian buffer on both stream margins every } \\
20 \mathrm{~m} \text { for each stream reach, and then calculated } \\
\text { the standard deviation of two sides }\end{array}$} \\
\hline & GRA & $37.3 \pm 39.1$ & \\
\hline & SHR & $18.5 \pm 15.4$ & \\
\hline & TRE & $17.0 \pm 18.8$ & \\
\hline & BAS & $7.5 \pm 12.8$ & \\
\hline & ROC & $5.3 \pm 13.7$ & \\
\hline & PTE & $1.0 \pm 4.9$ & \\
\hline & RLI & $12.7 \pm 11.3$ & \\
\hline \multicolumn{4}{|l|}{ Landscape } \\
\hline \multirow[t]{4}{*}{ Soil type } & $\begin{array}{l}\text { EP } \\
\text { OX }\end{array}$ & $\begin{array}{l}0.4 \pm 3.1 \\
48.9 \pm 48.5\end{array}$ & \multirow{4}{*}{$\begin{array}{l}\text { We estimated the percentage of each soil type for } \\
\text { each microbasin using the Ballester et al. (2012) } \\
\text { data set }\end{array}$} \\
\hline & UL & $38.1 \pm 46.8$ & \\
\hline & EN & $12.2 \pm 30.4$ & \\
\hline & $\mathbf{A L}$ & $0.4 \pm 2.8$ & \\
\hline Soil coverage & FO & $45.4 \pm 35.3$ & $\begin{array}{l}\text { We estimated the percentage of forest for each } \\
\text { microbasin based on Landsat images, and were } \\
\text { classified based on classification method according } \\
\text { Jensen (2000) in the program ERDAS (Version 9.2) }\end{array}$ \\
\hline \multirow[t]{2}{*}{ Spatial } & DI & $356.5 \pm 211.8$ & $\begin{array}{l}\text { We obtained the riverine distance between sites } \\
\text { because this variable is able to capture spatial } \\
\text { patterns that are not detected by overland } \\
\text { distances (Landeiro et al. 2011; } \\
\text { Casatti et al. 2012) }\end{array}$ \\
\hline & SUB & NA & $\begin{array}{l}\text { The sites were classified in eight of } 13 \text { subbasins, } \\
\text { and then this categorical variable was centralized }\end{array}$ \\
\hline
\end{tabular}

DEP, Depth (cm); WID, Width (cm); CUR, Current (cm/s); WTE, Water temperature $\left({ }^{\circ} \mathrm{C}\right)$; DOX, Dissolved oxygen $(\mathrm{mg} / \mathrm{l})$; CON, Conductivity $(\mu \mathrm{S})$; SIL, Silt (0.004-0.05 mm); SAN, Sand (0.05-2 mm); GRAV, Gravel (2-64 mm); BOU, Boulder (>256 mm); BED, Bedrock (>10 m); AVE, Attached vegetation (\%); CLI, Coarse litter (\%); BAT, Branches and tree trunks (\%); FRO, Fine roots (\%); CRO, Coarse roots exposed (\%); GRA, Grass (\%); SHR, Shrubs (\%); TRE, Trees (\%); BAS, Bare soil (\%); ROC, Rocks (\%); PTE, Pteridophytes (\%); RLI, Riparian litter (\%); EP, Eptisol (\%); OX, Oxisol (\%); UL, Ultisol (\%); EN, Entisol (\%); AL, Alfisol (\%); FO, Forest (\%); DIS, Fluvial distance between 52 sites of Machado River basin (km); SUB, Subbasin; NA, Not applicable. The variable codes in bold indicate variables removed for further analyses due to many absences in the matrix or high correlation coefficients $(\geq 0.8$ or $\geq-0.8)$ 
(Table 1) are recognized as drivers for stream fish species distribution and abundance: i) hydrological attributes (Angermeier and Karr 1994); ii) physicochemical attributes (Mendonça et al. 2005; Araújo and TejerinaGarro 2009); iii) composition of the channel substrate (Poff and Allan 1995); iv) riparian vegetation cover (Mérigoux et al. 1998; Stauffer et al. 2000; Pusey and Arthington 2003; Growns et al. 2003; Lorion and Kennedy 2009); v) microbasin soil type and; vi) microbasin soil coverage (Schlosser 1991; Fausch et al. 2002; Fernandes et al. 2012).

To represent the spatial variables were obtained two predictors, the fluvial distance and subbasins. The fluvial distance was estimated using a triangular matrix containing the watercourse distance between sites with the Network Analyst extension in the ArcGIS software (Version 9.3). Due to long distances among sites, the categorical variable subbasin was included, this information was obtained from ANA (2017).

Fish sampling

To collect fish, we adopted a combination of gear in order to use the most appropriate gear for each mesohabitat within each stream reach. We used a hand seine $(2 \mathrm{~mm}$ mesh) for runs and pools with a sandy bottom and without submerged structures and a dip net ( $2 \mathrm{~mm}$ mesh) for riffles and pools with hard substrate, trunks, and branches on the banks or in the bottom. The hand seine was operated by two collectors, and the collection effort was standardized for all reaches, being one hour long in each reach. We fixed the fishes in a $10 \%$ formalin solution and later transferred them to a $70 \%$ ethanol solution. We deposited all collected specimens in the fish collection of the Department of Zoology and Botany (DZSJRP), São Paulo State University (UNESP), São José do Rio Preto, São Paulo, Brazil.

Deconstruction by regionally occupancy

\section{Testing the pattern of spatial distribution in fish metacommunity}

The occupancy of each fish species $(\mathrm{S}=121)$ was described as the proportion of reach streams occupied; species-occupancy histogram was graphed; the $\mathrm{x}$-axis denoted 10 classes of species proportional occupancies (from 0 to 0.1 to $0.9-1.0$ ), the $y$-axis represented the number of species present in each class. The modality of the occupancyfrequency distribution (OFD) in the fish metacommunity was tested using the "bimodal" species frequency distribution proposed by Tokeshi (1992), used by Heatherly et al. (2007) and Heino (2015). The Mitchell-Olds \& Shaw Test for the Location of Quadratic Extreme (MOStest) was used to execute the Tokeshi's test (Oksanen et al. 2011)

\section{Using the form of OFD to deconstruct} the metacommunity in intermediate and satellite species

Separation of species or individuals based on measures of OFD's, using ten classes of species proportional occupancies, has been used for different freshwater taxa at assemblage level, for example, fish assemblages (Hugueni 1990, epiphytic chrironomid assemblages (Tokeshi 1992), the meta-analysis of datasets of plants, vertebrates and invertebrates (McGeoch and Gaston 2002) and stream insect assemblages (Heino 2015). At metacommunity level exists some studies for different taxa, for example, the meta-analysis of datasets of aquatic and terrestrial plants, vertebrates and invertebrates (Jenkins 2010), and tropical arboreal ants (Livingston and Philpott 2010).

We used the concept of regionally occupancy proposed by Hanski (1982), and separated the groups of species according the criteria commonly used (Heatherly et al. 2007; Heino 2015), core species were defined as those occupying $>90 \%$ and satellite species occupied $\leq 10 \%$ of the 52 stream reaches sampled. The proportion of sites occupied varied from 0.02 (one site) to 0.69 (36 sites). Among the 121 species, 45 were found only once (0.02) or twice (0.04) in the Machado River basin, due to their limited occurrence these singletons and doubletons were excluded from the analysis. Values from 0.06 to 0.10 were narrow range species considered as satellite species; values from 0.11 to 0.90 were medium range species considered as intermediate species; values from 0.91 to 1.00 , corresponding to core species were not founded. In this manner, we produced three data sets, one with all species, (AS), one with only intermediate species (IS), and one with satellite species (SS) (Fig. 2 Table 2). 


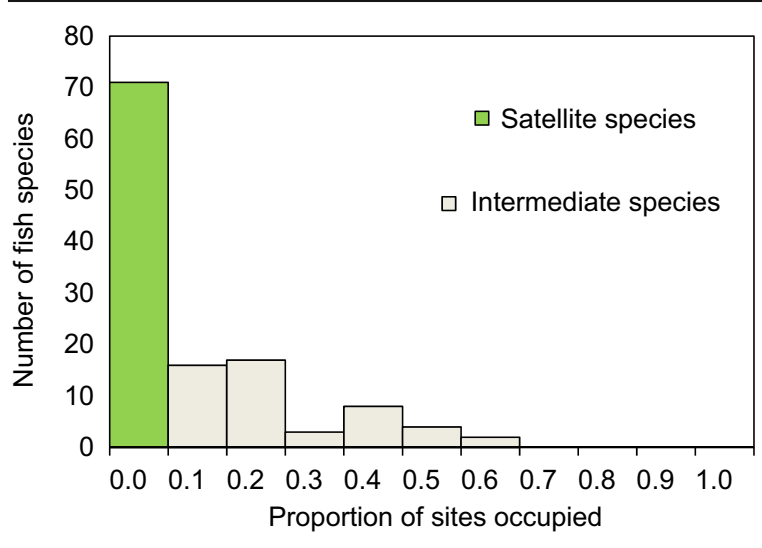

Fig. 2 Occupancy frequency distribution (OFD) for 121 fish species from Machado River basin. OFD is significantly unimodal and right-skewed $\left(P_{\mathrm{c}}=0.106 ; P_{1}<0.001 ; P_{\mathrm{r}}=0.103\right)$

Data analysis

\section{Standardizing and removing variables}

The species abundance matrix was standardized using the Hellinger standardization method (Legendre and Gallagher 2001).

Ten of 29 environmental variables were removed. The percentage of bedrock, pteridophytes, eptisol, entisol and alfisol were eliminated because they had many zero entries in the matrix; water temperature, conductivity and boulder were removed due to positive correlations with bare soil, grass, and cobble, respectively $(\geq 0.8$, $P<0.005)$; and width and dissolved oxygen were removed due to negative correlations with depth and coarse litter, respectively $(\geq-0.8, P<0.005)$. The 19 environmental variables remaining were centralized.

To construct spatial variables representing structures of all relevant scales, we used the "pcnm" function from the vegan package, this function computes PCNM (principal coordinates of neighbour matrices) by the principal component analysis of the truncated riverine distance matrix. Following the procedure proposed by Borcard et al. (2011), only the PCNM variables with positive spatial correlation are selected; consequently, from 39 PCNM variables created, were selected ten. Considering that sites are spatially aggregated in some subbasins and the long distance between sites, subbasin was included as a spatial categorical variable, this information was extracted from ANA (2017); the sites were classified in eight from 13 subbasins of Machado River basin. The ten PCNM variables selected and subbasin were centralized.
Thus, for subsequent analyses, we took into account 19 explanatory environmental variables for all data sets; 10 explanatory spatial variables for intermediate species and all species; and six explanatory spatial variables for satellite species.

\section{Selecting the explanatory variables}

A subset of explanatory environmental (local or landscape scale) and spatial (PCNM variables and subbasin) variables for each group (all species, intermediate species, and satellite species) were selected using the modified forward selection procedure, proposed by Blanchet et al. (2008). In this method, the global model using all explanatory variables is tested, and the analysis proceeds if the result is significant. Then the forward selection considers two additional criteria, namely the alpha significance level of each explanatory variable, and the adjusted coefficient of multiple determination $\left(R^{2}\right.$ adj) calculated with all explanatory variables. Accordingly, an explanatory variable is selected if $P<0.05$ and if its $\mathrm{R}^{2}$ adj does not exceed the $\mathrm{R}^{2}$ adj of the full model (Blanchet et al. 2008; Algarte et al. 2014).

\section{Determining the importance of the environmental and spatial variables in the three groups}

Finally, we conducted a partial Redundancy Analysis (pRDA) to estimate the relative importance of explanatory environmental (local and landscape) and spatial (fluvial distance and subbasins) variables in explaining the variation in abundance-weighted species composition. This method is an extension of the linear regression, with corresponding $R^{2}$ measures and the amount of variation that can be attributed to independent sets of explanatory variables: environmental (E), or spatial (S) (Cottenie 2005; Borcard et al. 1992). We applied the unbiased variation partitioning analysis suggested by Peres-Neto et al. (2006) to calculate the variance explained exclusively to $\mathrm{E}$ or $\mathrm{S}$. We carried out a separate analysis for each group of species (All species, intermediate species, and satellite species).

According to Borcard et al. (1992) and Cottenie (2005), the following are the different components of environmental and spatial variation: total explained variation $[\mathrm{E}+\mathrm{S}]$, environmental variation [E], spatial variation [S], environmental variation without the spatial component $[\mathrm{E} \mid \mathrm{S}]$, and spatial variation without the environmental component $[\mathrm{S} \mid \mathrm{E}]$. We tested the 
Table 2 Intermediate and satellite stream fishes according their occupancy-frequency distributions (OFDs)

\begin{tabular}{|c|c|c|c|}
\hline Proportion of sites occupied & Number of species & Species classification & Species \\
\hline 0.02 & 29 & Singletons & $\begin{array}{l}\text { barste, brasp1, brypir, cenper, cetsp3, } \\
\text { chagom, coramb, corbon, curmac, } \\
\text { cypplu, hypsp, lorcat, meldis, melpec, } \\
\text { micpoe, moegrac, moepan, parnas, } \\
\text { parsp, phebol, poteig, potorb, pronig, } \\
\text { pyrzig, rivsp, stegue, tataul, tetarg, tytmad }\end{array}$ \\
\hline 0.04 & 16 & Doubletons & $\begin{array}{l}\text { aptalb, astmac, batvil, cetsp1, cetsp2, corele, } \\
\text { corste, densed, helgou, hemnep, juppor, } \\
\text { mylsp, otohop, parari, phesp, rinsp }\end{array}$ \\
\hline 0.06 & 26 & Satellite species & $\begin{array}{l}\text { acefal, coracu, hembel, hoplit, hopuni, hypben, } \\
\text { jupzon, micsp, moegran, parpor, pimsp, rhaque, } \\
\text { squema, acacat, astmax, batran, brasp3, carstr, } \\
\text { cicama, hemmel, hypcop, knohet, micwei, moebon, } \\
\text { odofug, pseama }\end{array}$ \\
\hline 0.11 & 16 & Intermediate species & $\begin{array}{l}\text { brasp2, elapul, hypagu, megpic, gymcar, hemoce, } \\
\text { hyppyr, satjur, brypal, eryery, gymara, micgua, } \\
\text { moemik, cypspi, pimhow, moecot }\end{array}$ \\
\hline 0.21 & 17 & & $\begin{array}{l}\text { faroxy, gymcor, hyphet, hyplep, impsti, stefas, } \\
\text { synmar, eigtri, lassch, lepfri, cortri, imphas, } \\
\text { ituama, apires, anclit, astbim, stemac }\end{array}$ \\
\hline 0.31 & 3 & & sermic, jupcit, gympet \\
\hline 0.41 & 8 & & $\begin{array}{l}\text { bracop, pheret, pyraus, hopmal, rinhet, sernot, } \\
\text { knosmi, moecol }\end{array}$ \\
\hline 0.51 & 4 & & cresan, aeqtet, crepet, brycau \\
\hline 0.61 & 2 & & moeoli, chazeb \\
\hline $0.71-0.90$ & 0 & & Species not found \\
\hline $0.91-1,00$ & 0 & Core species & Species not found \\
\hline
\end{tabular}

For species codes see Online Resource 1. The species classification in bold indicate species excluded for further analyses due to many absences in the matrix

significance of these components with Monte Carlo permutation tests ( 999 permutations) and inferred which metacommunity perspectives best explain each data set, based in significance of each component, the cut-off point defined was $\alpha=\sim 5 \%$.

The correlation matrix was carried out in Statistica 12. The remaining analyses were carried out in $\mathrm{R} 2.15 .2$ (R Development Core Team 2011); the vegan package was used to standardize the variables, to execute the MOS test and the pRDA; the PCNM package was used to create and select the PCNM variables; and the packfor package was used to model selection.

\section{Results}

All data sets were all significantly related to environmental variables (at local and landscape scales) in the global environmental RDA model (PGenv).
All data sets were all significantly related to spatial variables in the global environmental RDA model (PGspa). All data sets were all significantly related to the pure spatial fraction ([SIEI]) in the RDA: overall fish assemblage $\left(\mathrm{R}^{2} \mathrm{adj}=0.078\right.$; $P=0.0001)$, intermediate species set $\left(\mathrm{R}^{2} \mathrm{adj}=0.057 ; P=0.0001\right)$ and satellite species set $\left(\mathrm{R}^{2} \mathrm{adj}=0.095 ; P=0.0001\right)$. Only satellite species set was significantly related to the pure environmental fraction ([EISI]) $\left(\mathrm{R}^{2} \mathrm{adj}=0.12\right.$; $P=0.0001$ ) (Table 3).

Two environmental variables were the most important to explain fish community structure for all data sets: percentage of forest at microbasin scale (FO) and the percentage of trees at the stream reach riparian buffer scale (TRE) (Table 4). The other significant environmental variables to explain fish assemblage composition, but with a very low variance explanation for each data set for overall fish assemblage was ultisol (UL); 
Table 3 Variation partitioning of the Hellinger-transformed fish abundance for each data set using partial redundancy analysis (pRDA). AS, entire fish metacommunity (all species); IS, intermediate species; SS satellite species

\begin{tabular}{llll}
\hline Data set & AS & IS & SS \\
\hline$P G e n v$ & $0.005^{* *}$ & $0.005^{* *}$ & $0.005^{* *}$ \\
Env R ${ }^{2}$ adj cum $(\%)$ & 17.3 & 22.1 & 12.6 \\
Env.sel & FO, TRE, UL & FO, TRE, UL, OX & FO, TRE, BAS, BAT, SAN \\
$P$ Gspa & $0.005^{* *}$ & $0.005^{* *}$ & $0.005^{* *}$ \\
Spa.sel & DI1, DI2, DI3, SUB, DI4 & DI1, DI2, DI3, DI4, SUB & DI1, DI2, DI4, DI5 \\
$\mathrm{R}^{2}$ adj [E|S] $(\%)$ & 3.3 & 3.7 & 11.7 \\
$\mathrm{R}^{2}$ adj $[\mathrm{S} \mid \mathrm{E}](\%)$ & 7.8 & 5.7 & 9.5 \\
$\mathrm{R}^{2}$ adj $[\mathrm{E}+\mathrm{S}](\%)$ & 14.1 & 18.4 & 1.0 \\
$P[\mathrm{E} \mid \mathrm{S}](\%)$ & $0.0016^{* *}$ & $0.0018^{* *}$ & $0.0001 * * *$ \\
$P[\mathrm{~S} \mid \mathrm{E}](\%)$ & $0.0001^{* * *}$ & $0.0001 * * *$ & $0.0001 * * *$ \\
$\mathrm{MC} \mathrm{P}$ & Dispersal-based processes & Dispersal-based processes & Niche and dispersal-based processes
\end{tabular}

PGenv: $P$ values of global environmental models; significance values. Env.sel: selected environmental variables; $P$ Gspa: $P$-values of global spatial models including eigenvectors associated with positive eigenvalues; Spa.sel: selected spatial vectors; $\mathrm{R}^{2}$ adj $[\mathrm{E} \mid \mathrm{S}],[\mathrm{S} \mid \mathrm{E}],[\mathrm{E}+\mathrm{S}](\%)$ : proportion of cumulated assemblage variation explained by pure environmental, pure spatial, and shared fractions; $P[\mathrm{E} \mid \mathrm{S}]: P$ values associated with the pure environmental fractions, $P[\mathrm{~S} \mid \mathrm{E}]: P$-values associated with the pure spatial fractions; MC P: metacommunity perspectives inferred. ' $P<0.1$; $: P<0.05$; **: $P<0.01$; ***: $P<0.001$; ****: $P<0.0001 ; P$ values are based on 9999 permutations. FO, Forest; TRE, Trees; UL, Ultisol; SHR, Shrubs; OX, Oxisol; BAS, Bare soil; BAT, Branches and tree trunks; SAN, Sand. DI1-DI5, Eigenvectors with positive correlation; SUB Subbasin

fore intermediate species set were ultisol (UL) and oxisol (OX); and for satellite species set were bare soil (BAS), branches and tree trunks (BAT) and sand (SAN). The amount of the variance explained by environmental variables was different for each data set. The entire fish metacommunity and intermediate species were mostly explained by landscape-scale variables, $12.4 \%$ and 16.8 of the variance respectively; local-scale variables explained $4.9 \%$ and $5.3 \%$ of the variance respectively (Fig. 3, Table 4). The satellite species set was mostly explained by local-scale variables, $8.7 \%$ of variance, and landscape-scale variables were of minor importance explained $3.7 \%$ of the variance (Fig. 3, Table 4).

Table 4 Relative contribution ( $\mathrm{R}^{2}$ adj) of selected environmental variables (Env.sel) for the entire fish metacommunity (all species), for the intermediate species (IS) and satellite species (SS)

\begin{tabular}{|c|c|c|c|c|c|c|}
\hline Data set & AS & & IS & & SS & \\
\hline Env.sel. & $\mathrm{R}^{2} \operatorname{adj}(\%)$ & $P$ & $\mathrm{R}^{2} \operatorname{adj}(\%)$ & $P$ & $\mathrm{R}^{2} \operatorname{adj}(\%)$ & $P$ \\
\hline FO & 11.0 & $0.0001 * * * *$ & 12.5 & $0.0001 * * * *$ & 3.9 & $0.0002 * * *$ \\
\hline UL & 1.4 & $0.0164 *$ & 1.6 & $0.0101 *$ & - & - \\
\hline OX & - & - & 2.7 & $0.0008 * * *$ & - & - \\
\hline TRE & 4.9 & $0.0001 * * * *$ & 5.3 & $0.0001 * * * *$ & 2.9 & $0.0030 * *$ \\
\hline BAS & - & - & - & - & 2.4 & $0.0049 * *$ \\
\hline BAT & - & - & - & - & 1.6 & $0.0466^{*}$ \\
\hline SAN & - & - & - & - & 1.8 & $0.0296^{*}$ \\
\hline Landscape-scale & 12.4 & & 16.8 & & 3.9 & \\
\hline Local-scale & 4.9 & & 5.3 & & 8.7 & \\
\hline
\end{tabular}

Landscape variables: FO, Forest; UL, Ultisol; OX, Oxisol. Local scale variables: TRE, Trees; BAS, Bare soil, BAT, Branches and tree trunks; SAN, Sand

$P<0.1 ; *: P<0.05$; **: $P<0.01 ; * * *: P<0.001 ; * * * *: P<0.0001 ; P$-values are based on 9999 permutations 
$\square R 2$ adj $[E+S] \quad \square R 2$ adj [SIE] $\quad \square R 2$ adj [EIS]

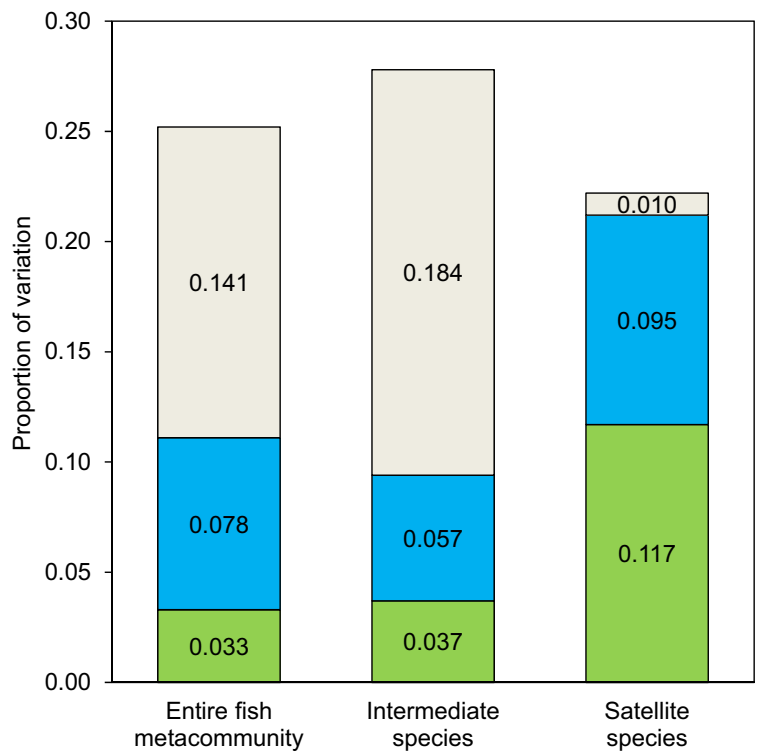

Fig. 3 Variance partitioning of the whole fish metacommunity, intermediate species, and satellite species. $[\mathrm{E} \mid \mathrm{S}]$ pure environmental (according local and landscape scales) fraction, $[\mathrm{E}+\mathrm{S}]$ shared fraction, and $[\mathrm{S} \mid \mathrm{E}]$ pure spatial fraction

The spatial variable riverine distance was the most important to explain fish community structure for satellite species; whereas the spatial variables riverine distance and subbasin were the most important to explain fish community structure for overall fish assemblage compositions and intermediate species set.

\section{Discussion}

Contrary to our first expectation, although the intermediate species presented significant $P$-values associated with the pure environmental fractions and the pure spatial fractions (fitting the species sorting and mass effect metacommunity models), the low contribution of the pure environmental component makes weak any inference on niche-based processes. Dispersal is well recognized as a key process structuring freshwater fish communities (Taylor and Warren 2001); however, for many stream fishes, the real role of dispersion is poorly known. Other studies suggest that habitat-specialist stream fish demonstrate high endemism due to their reduced capacity of displacement (Castro 1999; Gerhard 1999). Niche-based processes are a consistent and strong driver only of the satellite species set, this assemblage were influenced mainly by local-scale environmental variables, and this result upheld our second expectation. Finally, our last expectation was corroborated, the metacommunity set and the satellite species revealed the same pattern, only the spatial component was significant.

The importance of niche-based processes for satellite species is consistent with the evidence registered for habitat specialists in other deconstructive studies of freshwater metacommunities (Urban 2004; Cottenie 2005; Pandit et al. 2009; Algarte et al. 2014; Petsch et al. 2015). Our analysis revealed the importance of allochthonous resources at the local-scale and landscape for headwater stream fishes of the Machado River basin, because trees at the stream riparian buffer, and mature forest at the microbasin, explain the greatest portion of the variation of fish community structure in the specialist species set. For the data set including all of the species and the intermediate species, the variance of selected environmental variables was explained mainly by landscape scale variables.

According to Heino (2013), there are two kinds of metacommunity-structuring forces of different origins: the natural (biogeography) and the anthropogenic ones (land use). The "natural driver" of the studied basin presumes a common history with the Paraguay River basin in the south portion (Carvalho and Albert 2011) and with the Madeira River in the north portion of the basin. Therefore, the species pool within the Machado River basin was formed by distinct events during its history. The deforestation may be is acting as an "anthropogenic driver", modifying the patterns of local coexistence of similar species that have similar requirements (Leibold 1998).

Secondly, land use changes (i.e. from forests to cleared forest lands from agriculture, or from forests to pasture grasses) represent one of the most important threats to aquatic communities, these changes lead to the reduction of connectivity between local communities (Heino 2013) and modify metacommunity dynamics, which can speed up extinction processes by hindering overall dispersion, the dispersal of the species pool from the main channel to the tributaries, and also the dispersion from the other tributaries. With the results obtained for pure spatial structure, the intermediate species set and the metacommunity set are able to disperse throughout the riverine network and throughout the subbasins, establishing in environmentally suitable sites. Contrary, the satellite species only are able to 
disperse throughout the riverine network but not among subbasins. Probably it happens because satellite species are more restricted and the riverine distances between sites are shortest than distances between subbasins, considering that most of the sites of satellite species (26 streams $=\sim 70 \%$ of the sites) are restricted to three subbasins that contains most of fish species abundances (1268 individuals $=\sim 79 \%$ of the abundances). Therefore, the composition and abundances of the three data sets in this basin are affected in different ways by the changes in land use, which influence environmental variables (at landscape and local scale) and spatial variables.

The intermediate species set was influenced by dispersal processes; hence the spatial variable riverine distance act as a broad filter structuring this assemblage. The intermediate species shows broad environmental tolerances and can exploit structurally simplified streams localized in deforested areas where ultisol is dominant and/or heterogeneous streams where forested areas are predominant. In simplified streams, the ichthyofauna may respond to the degradation of the riparian buffer by shifting the species composition and the functional traits (Casatti et al. 2012), and by the dominance of opportunist and tolerant species (Casatti et al. 2009), such as the species Serrapinnus microdon and $S$. notomelas. It is well known that riparian vegetation in headwater streams (orders 1-3) influences the instream environment (Vannote et al. 1980; Schlosser 1982; Gregory et al. 1991; Pusey and Arthington 2003;
Sweeney and Blaine 2007; Sweeney and Newbold 2004). This riparian vegetation provides shade (Vannote et al. 1980) and, therefore, limits local productivity (Sabater et al. 2000). By contrast, logged riparian buffers exhibit high local productivity, notably filamentous algae (Biggs et al. 1998), increasing the amount of autochthonous resources that can be consumed by intermediate species, which are the most abundant in such conditions. In contrast, in structurally heterogeneous streams, other species of the intermediate species set also can take advantage of the allochthonous resources (woody elements, substrate heterogeneity, and mesohabitat heterogeneity) that are abundant in this scenario. The relatively more spaced-out distribution of intermediate species probably permit that can exploit both scenarios mentioned (homogeneous streams and heterogeneous streams)

The satellite species had specific demands that depend on allochthonous structures (e.g., fine roots, litter packs, branches, and trunks derived from trees and shrubs in the riparian buffer) (Fig. 4). For example, these structures benefit the reproductive guilds of some satellite species, as the brood hiders (Hyphessobrycon and Moenkhausia species) that spawn in contact with specific substrates often stream bottom or vegetal material, that provide cover for developing of ichthyoplankton; and the open substrate spawners (Pimellodella species), that scatter eggs over some substrate available in the water column (Winemiller et al. 2008). In clear contrast with the intermediate species, that they can survive in
Fig. 4 Stream sampled reach 10, Extractive Reserve Rio Preto Jacundá, Machadinho d'Oeste Municipality, Rondônia State, Brazil $\left(62^{\circ} 05^{\prime} 55^{\prime \prime} \mathrm{W}, 09^{\circ} 06^{\prime} 15^{\prime \prime}\right.$ S). Photograph by M.A. PérezMayorga, 2012

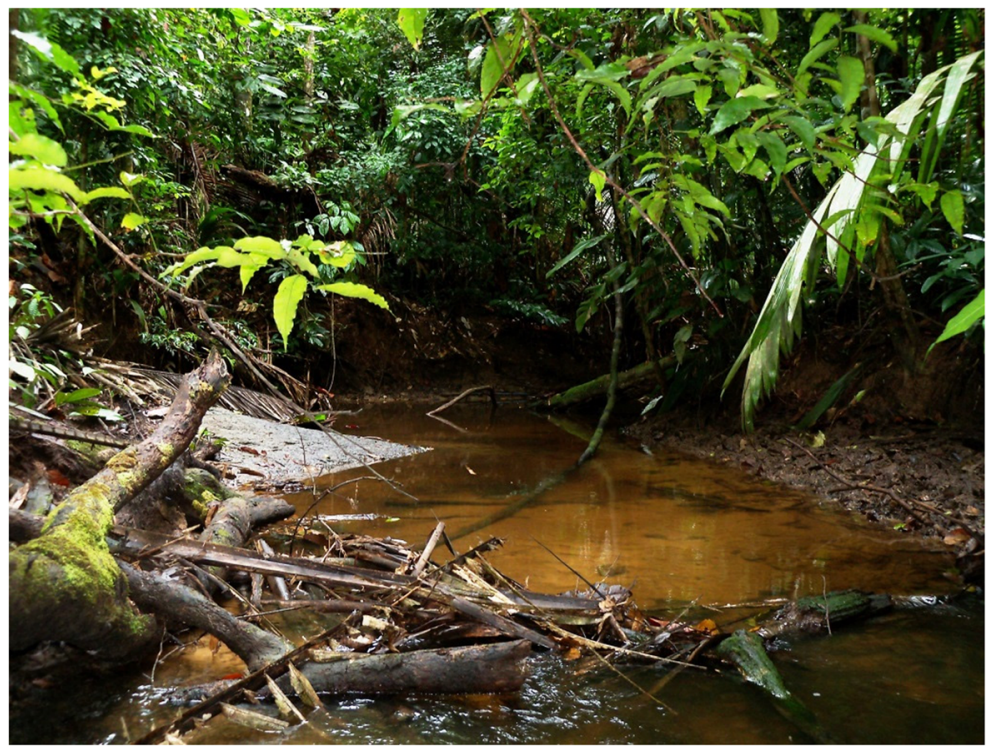


Fig. 5 Stream sampled reach 48 , Rolim de Moura Municipality, Rondônia State, Brazil (613' $\left.41^{\prime \prime} \mathrm{W}, 11^{\circ} 50^{\prime} 17^{\prime \prime} \mathrm{S}\right)$ Photograph by M.A. Pérez-Mayorga, 2012

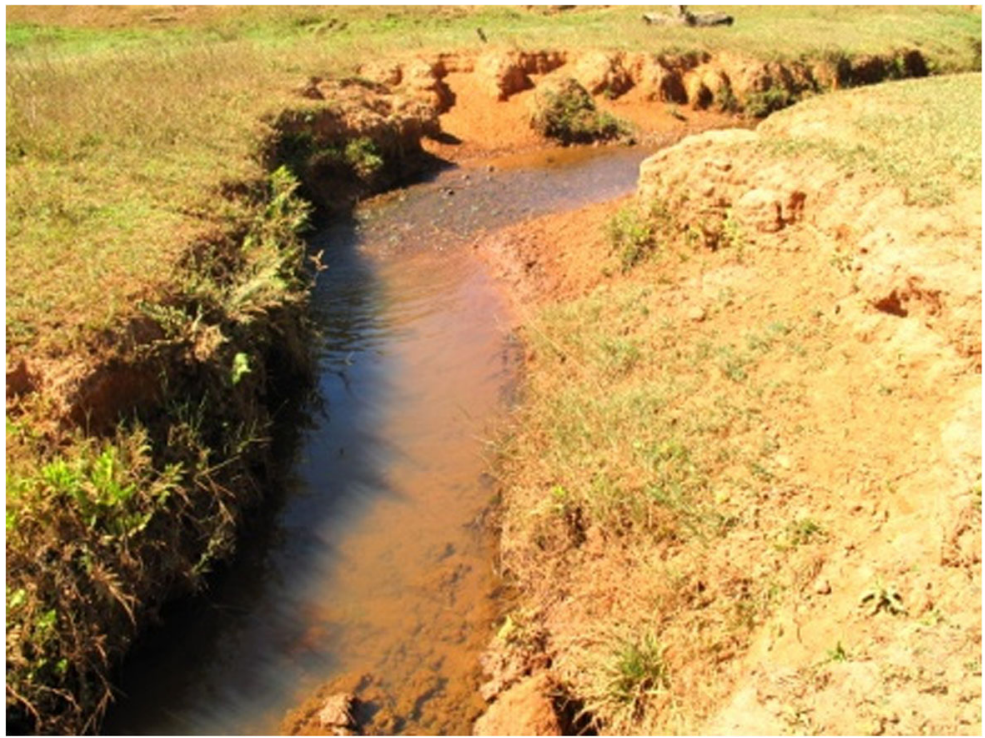

homogeneous streams whereas these structures are absent (Fig. 5). The organic material intake deposited on the forest floor can be moved into the streams by wind (Elosegi and Pozo 2005) and mainly surface runoff during high water levels. These elements can contribute to mesohabitat (e.g. pools, riffles, runs) and microhabitat (e.g., substrate type, water depth, current) variability (Frissell et al. 1986). In this context, both species groups (the intermediate and satellite species) can exploit mesoand microhabitats for foraging, reproduction and shelter, but in absence of these structures the satellite species would be unable to survive.

It is important to mention, that the amount of unexplained variation obtained for each data set were high. This pattern is very common in ecological studies and probably is caused by noise in species abundance or occurrence data sets (ter Braak and Šmilauer 1998; Titeux et al. 2004). Likely, other important variables not included in this study, such as biotic interactions (Pandit et al. 2009) and/or spatiotemporal stochastic events (Titeux et al. 2004) that affect the composition and abundances of stream fishes, may help to explain the residuals.

In summary, our findings revealed that exists distinct responses between intermediate and satellite stream fish species from the Amazonian Machado River basin, the intermediate species are explained only by dispersalbased processes, and the satellite species are mainly explained by two processes, mainly niche-based processes and secondly by dispersal-based processes.
Comparing our results with Pandit et al. (2009) predictions, the fish metacommunity studied has the same pattern of invertebrate metacommunity from Jamaican rock pool, satellite species has the same pattern of habitat specialists and intermediate species has the same pattern of habitat generalists.

The results of this deconstructive framework suggest that conservation and maintenance of regional biodiversity depend on the knowledge of the regional species pool and the specific demands of habitat specialization. Because traditional metacommunities analyses are conducted with the entire set of species, they neglect any conclusion about the specific requirements of species. Just as important as discriminating habitat requirements for each species set is to understanding how different sets and scales of variables are related to different species sets. Specifically, for river basins that were recently deforested, remnants of preserved areas could be of great value because they are still able to harbor subsets of satellite species that can play a role as source assemblages in the regional context.

Acknowledgements This study was made possible by a collecting license provided by the Instituto Brasileiro do Meio Ambiente e dos Recursos Naturais Renováveis IBAMA (4355-1) and by funding provided by the Fundação de Amparo à Pesquisa do Estado de São Paulo - FAPESP (2010/17494-8) and the Conselho Nacional de Desenvolvimento Científico e Tecnológico - CNPQ (306758/2010-5). The authors thank Fernando R. Silva, Mauricio Cetra, Tadeu Siqueira, Virgínia S. Uieda and Francisco Langeani for their useful comments on the manuscript. We thank 
the anonymous reviewers and the editor in Chief. MAPM received fellowship from the Programa de Apoio a Estudantes de Doutorado do Exterior AUIP/UNESP; FBT and LC are supported by the CNPq; GLB is supported by FAPESP (2012/21916-0 and 2015/05827-6). We thank the UEG for funding the manuscript translation.

\section{Compliance with ethical standards}

Conflict of interest The authors declare that they have no conflict of interest.

Ethical approval All applicable international, national, and/or institutional guidelines for the care and use of animals were followed.

\section{References}

Agência Nacional de Águas ANA (2017) HidroWeb Sistema de informações hidrológicas, Brasília http://hidroweb.ana.gov. br. Accessed June 2017

Algarte VM, Rodrigues L, Landeiro VL, Siqueira T, Bini LM (2014) Variance partitioning of deconstructed periphyton communities: does the use of biological traits matter? Hydrobiologia 722:279-290. doi:10.1007/s10750-0131711-6

Alvares CA, Stape JL, Sentelhas PC, Gonçalves JLM, Sparovek G (2014) Köppen's climate classification map for Brazil. Meteorol Z 22:711-728. doi:10.1127/0941-2948/2013/0507

Alves DS, Pereira JLG, Souza CL, Soares JV, Moreira JC, Ortiz JO, Shimabukuro YE, Yamaguchi F (1998) Classification of the deforested area in Central Rondônia using TM imagery. In: Rudorff BFT, Freitas UM (eds) Krug T. IX Simpósio Brasileiro de Sensoriamento Remoto, São Paulo, pp 1421-1432

Angermeier PL, Karr JR (1994) Biological integrity versus biological diversity as policy directives: protecting biotic resources. Bioscience 44:690-697

Araújo NB, Tejerina-Garro FL (2009) Influence of environmental variables and anthropogenic perturbations on stream fish assemblages, upper Paraná River, Central Brazil. Neotrop Ichthyol 7:31-38

Ballester MVR, de Victoria D C, Krusche AV, Victoria RL, Richey JE (2012) Soil classification map, Ji-Parana River basin, Rondônia, Brazil. Data set from Oak Ridge National Laboratory Distributed Active Archive Center, U.S.A. http://daac.ornl.gov. Accessed 7 Dec 2013

Biggs BJF, Kilroy C, Lowe RL (1998) Periphyton development in three valley segments of a New Zealand grassland river: test of a habitat matrix conceptual model within a catchment. Arch Mikrobiol 143:147-177. doi:10.1127/archivhydrobiol/143/1998/147

Blanchet FG, Legendre P, Borcard D (2008) Forward selection of explanatory variables. Ecology 89:2623-2632. doi:10.1890/070986.1
Borcard D, Legendre P, Drapeau P (1992) Partialling out the spatial component of ecological variation. Ecology 73 : 1045-1055. doi:10.2307/1940179

Borcard D, Gillet F, Legendre P (2011) Numerical ecology with R. Springer, New York

Brejão GL, Gerhard P, Zuanon J (2013) Functional trophic composition of the ichthyofauna of forest streams in eastern Brazilian Amazon. Neotrop Ichthyol 11:361-373. doi:10.1590/S1679-62252013005000006

Brown S, Lugo AE (1990) Tropical secondary forests. J Trop Ecol 6:1-32. doi:10.1017/S0266467400003989

Buckup PA, Menezes NA, Ghazzi MS (2007) Catálogo das espécies de peixes de água doce do Brasil. Série Livros 23, Rio de Janeiro

Calcagnotto D, Schaefer AS, DeSalle R (2005) Relationships among characiform fishes inferred from analysis of nuclear and mitochondrial gene sequences. Mol Phylogenet Evol 36: 135-153. doi:10.1016/j.ympev.2005.01.004

Carvalho TP, Albert JS (2011) The Amazon-Paraguay divide. In: Albert JS, Reis RE (eds) Historical biogeography of neotropical freshwater fishes. University of California Press, Berkley, pp 193-202

Carvalho LN, Fidelis L, Arruda R, Galuch A, Zuanon J (2013) Second floor, please: the fish fauna of floating litter banks in Amazonian streams and rivers. Neotrop Ichthyol 11:85-94. doi:10.1590/S1679-62252013000100010

Casatti L, Castro RMC (1998) A fish community of the São Francisco River headwater riffles, southeastern Brazil. Ichthyol Explor Freshw 9:229-242

Casatti L, de Paula FC, Carvalho FR (2009) Grass-dominated stream sites exhibit low fish species diversity and dominance by guppies: an assessment of two tropical pasture river basins. Hydrobiologia 632:273-283. doi:10.1007/s10750-009-9849-y

Casatti L, Teresa FB, Gonçalves-Souza T, Bessa E, Manzotti AR, Gonçalves CS, Zeni J (2012) From forests to cattail: how does the riparian zone influence stream fish? Neotrop Ichthyol 10: 205-214. doi:10.1590/S1679-62252012000100020

Casatti L, Pérez-Mayorga MA, Carvalho FR, Brejão GL, da Costa ID (2013) The stream fish fauna from the rio Machado basin, Rondônia state, Brazil. Check list 9:1496-1504. Doi: 10.15560/9.6.1496

Castro RMC (1999) Evolução da ictiofauna de riachos sulamericanos: padrões gerais e possíveis processos causais. Oecol Brasiliensis 6:139-155

Cottenie K (2005) Integrating environmental and spatial processes in ecological community dynamics. Ecol Lett 8:1175-1182. doi:10.1111/j.1461-0248.2005.00820.x

Elosegi A, Pozo J (2005) Litter input. In: Graça MAS, Bärlocher F, Gessner MO (eds) Methods to study litter decomposition. A Practical Guide. Springer, Dordrecht, pp 3-11

Fausch KD, Torgersen CE, Baxter CV, Hiram WL (2002) Landscapes to riverscapes: bridging the gap between research and conservation of stream fishes. Bioscience 52:483-498. doi:10.1641/0006-3568(2002)052[0483:LTRBTG]2.0.CO

Fernandes IM, Lourenço LS, Ota RP, Moreira MMM, Zawadzki CH (2012) Effects of local and regional factors on the fish assemblage structure in meridional Amazonian streams. Environ Biol Fish 96:837-848. doi:10.1007/s10641-012-0079-1

Ferraz SFB, Vettorazzi CA, Theobald DM, Ballester MVR (2005) Landscape dynamics of Amazonian deforestation between 1984 and 2002 in central Rondônia, Brazil: assessment and 
future scenarios. Forest Ecol Manag 204:69-85. doi:10.1016 j.foreco.2004.07.073

Frissell CA, Liss W, Warren CE, Hurley MD (1986) A hierarchical framework for stream habitat classification: viewing streams in a watershed context. Environ Manag 10:199-214. doi:10.1007/BF01867358

Gerhard P (1999) Ecologia de populações e comportamento de quatro espécies de bagres Heptapterinae (Teleostei: Siluriformes) em riachos do Alto Vale do rio Ribeira (Iporanga, São Paulo). Dissertation, Universidade de São Paulo

Gilpin ME, Hanski IA (1991) Metapopulation dynamics: empirical and theoretical investigations. Academic, London

Gregory SV, Swanson FJ, McKee WA, Cummins KW (1991) An ecosystem perspective of riparian zones. Bioscience 41:540-551

Growns IP, Gehrke C, Astles KL, Pollard DA (2003) A comparison of fish assemblages associated with different riparian vegetation types in the Hawkesbury-Nepean River system. Fish Manag Ecol 10:209-220. doi:10.1046/j.13652400.2003.00337.x

Hanski I (1982) Dynamics of regional distribution: the core and satellite species hypothesis. Oikos 38:210-221

Heatherly T, Whiles MR, Gibson DJ, Collins SL, Huryn AD, Jackson JK, Palmer MA (2007) Stream insect occupancyfrequency patterns and metapopulation structure. Oecologia 151:313-321. doi:10.1007/s00442-006-0596-8

Heino J (2013) The importance of metacommunity ecology for environmental assessment research in the freshwater realm. Biol Rev 88:166-178. doi:10.1111/j.1469-185 X.2012.00244.x

Heino J (2015) Deconstructing occupancy frequency distributions in stream insects: effects of body size and niche characteristics in different geographical regions. Ecol Entomol 40:491499. doi:10.1111/een.12214

Heino J, Soininen J (2010) Are common species sufficient in describing turnover in aquatic metacommunities along environmental and spatial gradients? Limnol Oceanogr 55:23972402. doi:10.4319/lo.2010.55.6.2397

Hughes RG (1986) Theories and models of species. Am Nat 128(15):1-11

Hugueni B (1990) Geographic range of west African freshwater fishes: role of biological characteristics and stochastic processes. Acta Oecol 11:351-375

Jacobson B, Peres-Neto PR (2010) Quantifying and disentangling dispersal in metacommunities: how close have we come? How far is there to go? Landsc Ecol 25:495-507. doi:10.1007/s10980-009-9442-9

Jenkins DJ (2010) Ranked species occupancy curves reveal common patterns among diverse metacommunities. Glob Ecol Biogeogr 20:486-497

Jensen JR (2000) Remote sensing of the environment: an earth resources perspective. Prentice-Hall, Bergen

Krumbein WC, Sloss LL (1963) Stratigraphy and sedimentation. Freeman, San Francisco

Krusche AV, Ballester MVR, Victoria RL, Bernardes MC, Leite NK, Hanada L, Victoria DC, Toledo AM, Ometto JP, Moreira MZ, Gomes BM, Bolson MA, Neto SG, Bonelli N, Deegan L, Christopher N, Thomas S, Aufdenkampe AK, Richey JE (2005) Efeitos das mudanças do uso da terra na biogeoquímica dos corpos d'água da bacia do rio Ji-Paraná,
Rondônia. Acta Amaz 35:197-205. doi:10.1590/S004459672005000200009

Landeiro VL, Magnusson WE, Melo AS, Espirito-Santo HMV, Bini LM (2011) Spatial eigenfunction analyses in stream networks: do watercourse and overland distances produce different results? Freshw Biol 56:1184-1192. doi:10.1111 j. 1365-2427.2010.02563.x

Legendre P, Gallagher ED (2001) Ecologically meaningful transformations for ordination of species data. Oecologia 129: 271-280. doi:10.1007/s004420100716

Leibold MA (1998) Similarity and local co-existence of species in regional biotas. Evol Ecol 12:95-110. doi:10.1023 /A: 1006511124428

Leibold MA, Holyoak M, Mouquet N, Amarasekare P, Chase JM, Hoopes MF, Holt RD, Shurin JB, Law R, Tilman D, Loreau M, Gonzalez A (2004) The metacommunity concept: a framework for multi-scale community ecology. Ecol Lett 7: 601-613. doi:10.1111/j.1461-0248.2004.00608.x

Livingston GF, Philpott SM (2010) A metacommunity approach to co-ocurrence patterns and the core-satellite hypothesis in a community of tropical arboreal ants. Ecol Res 25:1129-1140

Lorion CM, Kennedy BP (2009) Riparian forest buffers mitigate the effects of deforestation on fish assemblages in tropical headwater streams. Ecol Appl 19:468-479. doi:10.1890/08-0050.1

Lowe-McConnell RH (1975) Fish communities in tropical freshwaters. Longman, New York

Marquet PA, Fernández M, Navarrete SA, Valdovinos C (2004) Diversity emerging: towards a deconstruction of biodiversity patterns. In: Lomolino M, Heaney L (eds) Frontiers of biogeography: new directions in the geography of nature. Sinauer Associates, Sunderland, pp 191-209

May RM (1975) Patterns of species abundance and diversity. In: Cody ML, Diamond JM (eds) Ecology and evolution of communities. Belknap Press of Harvard University Press, Cambridge, pp 81-120

McGeoch MA, Gaston KJ (2002) Occupancy frequency distributions: patterns, artefacts and mechanisms. Biol Rev 77:311331. doi:10.1017/S1464793101005887

McMahon TE, Matter WJ (2006) Linking habitat selection, emigration and population dynamics of freshwater fishes: a synthesis of ideas and approaches. Ecol Freshw Fish 15: 200-210. doi:10.1111/j.1600-0633.2006.00130.x

Mendonça FP, Magnusson WE, Zuanon J (2005) Relationships between habitat characteristics and fish assemblages in small streams of Central Amazonia. Copeia 4:751-764

Mérigoux S, Ponton D, Mérona B (1998) Fish richness and species- habitat relationships in two coastal streams of French Guiana, South America. Environ Biol Fish 51:25-39

Nathan RG, Perry JT, Cronin A, Strand E, Cain ML (2003) Methods for estimating long-distance dispersal. Oikos 103: 261-273. doi:10.1034/j.1600-0706.2003.12146.x

Oksanen J, Blanchet FG, Kindt R, Legendre P, O'Hara RB, Simpson GL, Solymos P, Stevens MHH \& Wagner H (2011) vegan: community ecology package. R Package Version 1.17-8. Available at http://CRAN.R- project. org/package=vegan

Pandit SN, Kolasa J, Cottenie K (2009) Contrasts between habitat generalists and specialists: an empirical extension to the basic metacommunity framework. Ecology 90:2253-2262. doi:10.1890/08-0851.1 
Pazin VFV, Magnusson WE, Zuanon J, Mendonça FP (2006) Fish assemblages in temporary ponds adjacent to 'terra-firme' streams in Central Amazonia. Freshw Biol 51:1025-1037. doi:10.1111/j.1365-2427.2006.01552.x

Peres-Neto PR, Legendre P, Dray S, Borcard D (2006) Variation partitioning of species data matrices: estimation and comparison of fractions. Ecology 87:2614-2625. doi:10.1890/00129658(2006)87[2614:VPOSDM]2.0.CO;2

Petsch DK, Pinha GD, Dias JD, Takeda AM (2015) Temporal nestedness in Chironomidae and the importance of environmental and spatial factors in species rarity. Hydrobiologia 745:181-193. doi:10.1007/s10750-014-2105-0

Pielou EC (1975) Ecological diversity. Wiley, New York

Poff NL, Allan JD (1995) Functional organization of stream fish assemblages in relation to hydrological variability. Ecology 76:606-627

Pusey BJ, Arthington AH (2003) Importance of the riparian zone to the conservation and management of freshwater fish: a review. Mar Freshw Res 54:1-16. doi:10.1071 /MF020411323-1650/03/010001

R Development Core Team (2011) R: A Language and Environment for Statistical Computing v2.15.2. R Foundation for Statistical Computing. Vienna. http://www. R-project.org. Accesed 10 June 2014

Reis RE, Kullander SO, Ferraris CJ Jr (2003) Check list of the freshwater fishes of south and central America (CLOFFSCA). Edipucrs, Porto Alegre

Resck DVS (1992) Manejo e conservação do solo em microbacias hidrográficas na região dos Cerrados. EMBRAPA-CPAC, Planaltina

Sabater F, Butturini A, Marti E, Muñoz I, Romani A, Wray J, Sabater S (2000) Effects of riparian vegetation removal on nutrient retention in a Mediterranean stream. J N Am Benthol Soc 19:609-620

Schlosser IJ (1982) Fish community structure and function along two habitat gradients in a headwater stream. Ecol Monogr 52: 395-414. doi:10.2307/2937352

Schlosser IJ (1991) Stream fish ecology: a landscape perspective. Bioscience 41:704-712. doi:10.2307/1311765

Siqueira T, Bini LM, Roque FO, Marques Couceiro SR, TrivinhoStrixino S, Cottenie K (2012) Common and rare species respond to similar niche processes in macroinvertebrate metacommunities. Ecography 35:183-192. doi:10.1111 j.1600-0587.2011.06875.x

Stauffer JC, Goldstein RM, Newman RM (2000) Relationship of wooded riparian zones and runoff potential to fish community composition in agricultural streams. Can J Fish Aquat Sci 57:307-316

Sweeney BW, Blaine JG (2007) Resurrecting the in-stream side of riparian forests. J Contemp Water Res Educ 136:17-27

Sweeney BW, Newbold JD (2004) Streamside forest buffer width needed to protect stream water quality, habitat, and organisms: a literature review. J Am Water Resour Assoc 50:560584. doi:10.1111/jawr.12203

Taylor CM, Warren ML Jr (2001) Dynamics in species composition of stream fish assemblages: environmental variability and nested subsets. Ecology 82:2320-2330. doi:10.1890 /0012-9658(2001)082[2320:DISCOS]2.0.CO;2

ter Braak CJF, Šmilauer P (1998) CANOCO v4 reference manual and CanoDraw for windows user's guide: software for canonical community ordination. Microcomputer Power, Ithaca

Titeux N, Dufrêne M, Jacob JP, Paquay M, Defourny P (2004) Multivariate analysis of a fine-scale breeding bird atlas using a geographical information system and partial canonical correspondence analysis: environmental and spatial effects. J Biogeogr 31:1841-1856. doi:10.1111/j.13652699.2004.01125.x

Tokeshi M (1992) Dynamics of distribution in animal communities: theory and analysis. Res Popul Ecol 34:249-273

Torrente-Vilara G, Queiroz LJ, Ohara WM (2013) Um breve histórico sobre o conhecimento da fauna de peixes do Rio Madeira. In: Queiroz LJ, Torrente-Vilara G, Ohara WM, Pires THS, Zuanon J, Doria CRC (eds) Peixes do Rio Madeira Volume I. Dialeto, São Paulo, pp 18-25

Urban MC (2004) Disturbance heterogeneity determines freshwater metacommunity structure. Ecology 85:2971-2978. doi:10.1890/03-0631

Vannote RL, Minshall GW, Cummins KW, Sedell JR, Cushing CE (1980) The river continuum concept. Can J Fish Aquat Sci 37:130-137

Winemiller KO, Agostinho AA, Pellegrini-Caramaschi E (2008) Fish ecology in tropical streams in: dudgeon D (ed) tropical stream ecology, San Diego, pp 107-146 